\title{
The Oct-2 protein binds cooperatively to adjacent octamer sites
}

\author{
Jonathan H. LeBowitz, Roger G. Clerc, Michael Brenowitz, ${ }^{1}$ and Phillip A. Sharp \\ Center for Cancer Research and Department of Biology, Massachusetts Institute of Technology, Cambridge, Massachusetts \\ 02139 USA; $^{1}$ Department of Biochemistry, Albert Einstein College of Medicine, Bronx, New York 10461 USA
}

\begin{abstract}
Recombinant proteins derived from the cloned human oct-2 gene were used to investigate cooperative binding by Oct-2 to adjacent DNA-binding sites. Oct-2, a B-cell-specific transcription factor, binds tightly to the octamer sequence in immunoglobulin promoters. A second apparently unrelated consensus sequence in heavy chain promoters, the heptamer site, also is recognized by the Oct- 2 protein but with 1000 -fold lower affinity. Simultaneous occupancy of both the octamer and heptamer sites is favored by cooperative interactions. The heptamer site is probably recognized by the same binding surface in the Oct-2 protein as the octamer site and thus is conserved as a lower-affinity binding site. This permits the immunoglobulin promoter to respond to a much broader range of levels of Oct-2 protein. Substitution of prototype octamer sequences for heptamer sequences yields a probe with two octamer sites spaced by 2 nucleotides, which also binds Oct- 2 protein cooperatively. Only the POU domain in the Oct-2 protein is required for this cooperative interaction. Similar protein-protein interactions between bound Oct-2 proteins may promote promoter-enhancer synergism in the heavy chain gene.
\end{abstract}

[Key Words: Oct-2; cooperative binding; immunoglobulin transcription; transcription factor(s)]

Received June 27, 1989; revised version accepted August 4, 1989.

Cell-type-specific transcriptional control of gene expression generally is accomplished by the action of sequence-specific DNA-binding proteins that interact with promoters and enhancers (Maniatis et al. 1987; Jones et al. 1988|. The Oct- 2 protein, a sequence-specific DNA-binding protein that binds with high affinity to the sequence $5^{\prime}$-ATGCAAAT- $3^{\prime}$ (called the octamer site), activates transcription from immunoglobulin promoters both in vivo and in vitro (Landolfi et al. 1986; Staudt et al. 1986; Scheidereit et al. 1987; Wang et al. 1987; LeBowitz et al. 1988; Müller et al. 1988). Although the Oct- 2 protein is thought to be expressed only in lymphoid cells and mediate the cell-type-specific effects of the octamer site, a protein with identical DNAbinding specificity is constitutively synthesized in all cell types (Pruijn et al. 1986; Singh et al. 1986; Fletcher et al. 1987; Sturm et al. 1987, O'Neill and Kelly 1988). This protein, Oct-1, probably mediates activation of a number of constitutively expressed promoters that contain octamer sites. For example, transcription of genes encoding histones and small nuclear RNAs (snRNAs) depends on sequences recognized by Oct-1 (Mattaj et al. 1985; Mangin et al. 1986; Sive and Roeder 1986; Sive et al. 1986; Ares et al. 1987; Bark et al. 1987; Bohmann et al. 1987; Carbon et al. 1987; Krol et al. 1987; Murphy et al. 1987; Roebuck et al. 1987; Das et al. 1988).

The octamer site is present in the immunoglobulin heavy-chain promoter, in the opposite orientation in the $\kappa$ light-chain promoter and in the heavy-chain enhancer, which is located in a downstream intron (Banerji et al.
1983; Gillies et al. 1983; Falkner and Zachau 1984; Parslow et al. 1984; Grosschedl and Baltimore 1985; Mason et al. 1985). Each of these octamer sites is an independent cis-activator of transcription in lymphoid cells, presumably due to interactions with the Oct-2 protein (Bergmann et al. 1984; Falkner and Zachau 1984; Foster et al. 1985; Gopal et al. 1985; Picard and Schaffner 1985; Mizushima-Sugano and Roeder 1986; Dreyfus et al. 1987; Lenardo et al. 1987, Wirth et al. 1987). The octamer site is the predominant determinant of B-cell specificity in the promoters (Dreyfus et al. 1987; Wirth et al. 1987), whereas multiple sites are recognized by a variety of proteins that activate or suppress transcription in different cell types in the enhancer /Church et al. 1985; Ephrussi et al. 1985; Augereau and Chambon 1986; Schlokat et al. 1986; Sen and Baltimore 1986; Wasylyk and Wasylyk 1986; Weinberger et al. 1986, 1988; Gerster et al. 1987; Lenardo et al. 1987; Peterson and Calame 1987). There may be a synergistic interaction between the heavy chain promoter and its cognate enhancer. Exchange of either promoter or enhancer in this set with other elements that function in B cells reduces the level of transcription significantly /Garcia et al. 1986).

In the immunoglobulin heavy-chain promoter there is an additional conserved sequence, referred to as the heptamer site 5'-CTCATGA-3' (Ballard and Bothwell 1986; Eaton and Calame 1987; Landolfi et al. 1988). The position of the heptamer site varies in different heavy chain promoters, ranging from 2 to 22 nucleotides upstream of 
the octamer site. The heptamer site has been shown to contribute two- to fivefold to the transcriptional activity of the heavy chain promoter in vivo and in vitro (Eaton and Calame 1987; Poellinger et al. 19891. Although the heptamer site is not closely related in sequence to the prototype octamer site, recent evidence suggests that this site may be recognized by the Oct- 2 and Oct-1 proteins. Octamer-binding proteins purified from extracts of $B$ cells or HeLa cells (OTF- $2 \equiv$ Oct- 2 , OTF- $1 \equiv$ Oct- 1 ) specifically bind both octamer and heptamer sequences (Kemler et al. 1989; Poellinger and Roeder 1988; Poellinger et al. 1989). Interestingly, occupancy of the heptamer site by these two protein preparations did not occur if the adjacent octamer site was altered by mutation. This suggested a cooperative interaction between proteins bound to the adjacent two types of sites.

Recently, the genes encoding the Oct- 1 and Oct-2 proteins have been cloned (Clerc et al. 1988; Müller et al. 1988; Scheidereit et al. 1988; Staudt et al. 1988; Sturm et al. 1988). Although they are distinct genes, comparison of the derived amino acid sequences of these two proteins has revealed a region of remarkable structural similarity. The DNA-binding domains of both Oct-1 and Oct- 2 are related to the homeo box consensus and are identical at 55 of 62 amino acid residues. An adjacent region amino-terminal to the homeo box is also highly conserved between Oct-1 and Oct-2, with 74 of 75 amino acid residues being identical. This second homology has been extended to at least two other genes: the rat pit-1 gene, a rat pituitary-specific transcription factor, and unc-86, a Caenorhabditis elegans gene implicated in determining cell lineage and differentiation. In each of these proteins, this second homology resides adjacent to a well-conserved homeo box. The second conserved sequence, together with the adjacent homeo box, has been dubbed the POU domain (Herr et al. 1988). The POU domain is said to contain a POU box and a POU homeo box. The POU homeo box is believed to be responsible for the specific DNA binding of these proteins (Clerc et al. 1988; Ko et al. 1988; Garcia-Blanco et al. 1989). The POU box appears to stabilize high-affinity DNA binding (Sturm and Herr 1988); however, it is clearly dispensable for specific DNA binding, because one of the original Oct-2 cDNA clones isolated on the basis of specific binding to the octamer site contained less than half of the POU box (Staudt et al. 1988; Ko et al. 1988).

We used recombinant proteins derived from the Oct-2 cDNA to examine quantitatively the cooperative interaction between Oct- 2 molecules bound to heptamer and octamer sites and to two octamer sites. The results indicate that Oct- 2 binds cooperatively to both sets of sites and that the only protein determinant required for the cooperative interaction between adjacent Oct- 2 molecules is the highly conserved POU domain.

\section{Results}

Previous studies have shown that Oct-2 protein sequences containing the POU box bind with high speci- ficity and affinity to the octamer site in immunoglobulin promoters. Large amounts of a sequence-specific binding protein containing the POU box were isolated from bacteria expressing a Staphylococcus aureus protein A-Oct-2 fusion gene. The protein A sequence was joined to a partial Oct- 2 cDNA sequence (plasmid 3-1; Clerc et al. 1988) at the EcoRI site, immediately upstream of the POU box sequences. Approximately $40 \mathrm{mg}$ of the fusion protein (PAOct-2) was purified from bacteria by sequential chromatography on IgG-Sepharose and DNA-cellulose (see Materials and methods). The purified PAOct-2 protein resolved into two major bands with molecular weights of 57,000 and 51,000 , respectively, upon analysis by electrophoresis in SDS-polyacrylamide gels. The larger polypeptide corresponds to the predicted molecular weight of the fusion protein. The faster migrating species probably represents a proteolytic fragment. Recovery and renaturation of protein from either mobility species yielded a protein that specifically recognized the octamer sequence with high affinity.

Two different sources of proteins related to Oct-2 were used during the course of this study. The primary source was the purified PAOct- 2 protein, which is free of other mammalian cellular proteins. Thus, the binding characteristics of this protein represent the activities of the cDNA-encoded sequences. All previous studies of binding by Oct- 2 protein were performed with protein purified from B-cell extracts or reticulocyte lysates primed with RNA transcribed in vitro. These preparations could have been contaminated by other mammalian factors. The other source of Oct- 2 protein was material translated in vitro in reticulocyte lysates. RNAs encoding portions of the Oct- 2 protein were transcribed from the cDNA segment and added to the translation reaction. The latter source of protein permitted convenient manipulation of the Oct- 2 sequences but yielded a product contaminated by reticulocyte material.

\section{PAOct-2 binds cooperatively to adjacent heptamer and octamer sites}

It has been suggested that the Oct- 2 protein binds to the heptamer site $\left(5^{\prime}\right.$-CTCATGA-3') when positioned adjacent to an octamer site (Kemler et al. 1989; Poellinger and Roeder 1989). Such a potential cooperative interaction between bound proteins can be demonstrated in a gel shift assay by comparison of the DNA-protein complexes formed with a series of mutant and wild-type probes. The oligonucleotide probes used in these studies were derived from the immunoglobulin heavy-chain promoter $\mathrm{V}_{17.2 .25}$ (Grosschedl and Baltimore 1985). Probe $\mathrm{H}^{+} \mathrm{O}^{+}$contained the wild-type promoter sequence (positions -69 to -47 ) in which the heptamer site is separated by 2 nucleotides from the octamer site (Table 1 ). In probe $\mathrm{H}^{-} \mathrm{O}^{+}$, the heptamer site was specifically mutated by incorporating 5 nucleotide changes, whereas the octamer site and flanking sequences remained intact. Probe $\mathrm{H}^{+} \Delta \mathrm{O}$ contains the wild-type heptamer sequence and a deletion of the octamer site. Comparison of the 
Table 1. DNA probes used in the DNA-binding assays

\begin{tabular}{lll}
\hline Probe designation & Orientation & Sequence $^{a}$ \\
\hline $\mathrm{H}^{+} \mathrm{O}^{+}$ & $\cdots \cdots \longrightarrow$ & AATTCTGCCTCATGAGTATGCAAATCATG \\
$\mathrm{H}^{+} \Delta \mathrm{O}$ & $\cdots$ & AATTCTGCCTCATGAGTAG \\
$\mathrm{H}^{-} \mathrm{O}^{+}$ & $\longrightarrow$ & AATTCTGCAGGTCGAGTATGCAAATCATG \\
$2 \mathrm{xOA}$ & $\longrightarrow$ & AATTCTGATTTGCATGTATGCAAATCATG \\
$2 \mathrm{xOB}$ & $\longrightarrow$ & GATCATGCAAATGCATTTGCAT \\
$2 \mathrm{xOC}$ & $\longrightarrow$ & AATTCTGCATGATTTGCATGCAAATCATG \\
$2 \mathrm{xOD}$ & $\longrightarrow$ & AATTCTGATGCAAATGTATGCAAATCATG \\
\hline
\end{tabular}

a See Materials and methods.

concentrations of PAOct- 2 protein required to bind to the heptamer site in probes $\mathrm{H}^{+} \mathrm{O}^{+}$and $\mathrm{H}^{+} \Delta \mathrm{O}$ permitted estimation of the cooperative interactions between bound Oct- 2 proteins.

Titration of added PAOct-2 protein revealed three sets of complexes with the $\mathrm{H}^{+} \mathrm{O}^{+}$probe (Fig. 1). $\mathrm{B} 1$ complex, which forms at low protein concentrations, primarily reflects binding of PAOct-2 to the octamer site. This assignment has been confirmed by methylation interference and copper/phenanthroline footprint analysis (Figs. $2 \mathrm{~B}$ and $5 \mathrm{~A}$ ). Complex B2 had a slower mobility and only formed at higher protein concentrations. Appearance of B2 required an intact heptamer sequence (Fig. 1A, cf. lanes designated $500, \mathrm{H}^{+} \mathrm{O}^{+}$and $\left.\mathrm{H}^{-} \mathrm{O}^{+}\right)$. The slower mobility of this complex, together with the observation that its formation depended on the presence of the heptamer sequence, suggested that B2 was the result of simultaneous binding of PAOct- 2 proteins to the octamer and heptamer sites. That complex B2 contained two protein molecules bound to the DNA was confirmed by detection of a heterodimer-type complex with two different sized Oct-2-related proteins produced by translation in vitro were added to the reaction simultaneously (data not shown). Also, methylation interference analysis of the B2 complex generated by PAOct-2 confirmed the occupancy of both the octamer site and heptamer sites (Fig. 2B). The B3 complex only formed at high protein concentrations and required that the probe contain both an intact heptamer and octamer site. The specific sequences bound in this complex have not been determined, and it is unclear whether they represent the binding of three or more proteins.

A titration of the binding of the PAOct- 2 protein to the $\mathrm{H}^{+} \Delta \mathrm{O}$ probe was generated also (Fig. 1). A complex with a mobility similar to that of B1 was only detected with this probe at high protein concentrations (Fig. 1A). This complex was shown to be due to specific interaction of the protein with the heptamer site by methylation interference analysis (Fig. 2A) and because the complex could be specifically competed by fragments that contained either the heptamer or octamer sites (data not shown).

Is the binding of PAOct- 2 to the adjacent octamer and heptamer sites cooperative? Cooperativity can be assessed by comparing the protein concentrations required to generate equivalent occupancy of the heptamer site in the $\mathrm{H}^{+} \mathrm{O}^{+}$and $\mathrm{H}^{+} \Delta \mathrm{O}$ probes. Because the affinity of PAOct- 2 for the heptamer site is much less than that for the octamer site (see below), fractional occupancy of the heptamer site in probe $\mathrm{H}^{+} \mathrm{O}^{+}$can be approximated by levels of the doubly liganded $\mathrm{H}^{+} \mathrm{O}^{+}$probe (complex $\mathrm{B} 2$ ). The fraction of probe $\mathrm{H}^{+} \mathrm{O}^{+}$in the doubly liganded complex B2 was compared with amounts of $\mathrm{H}^{+} \Delta \mathrm{O}$ complex in Figure 1B. About 50- to 100-fold higher levels of protein were required to generate equivalent levels of occupancy of the heptamer site in the latter probe, indicating a 50 - to 100-fold increase in the affinity for binding to the heptamer site when the adjacent octamer site is occupied. As discussed later, the association constant for PAOct-2 binding to the octamer site is $\sim 6 \times 10^{8} / \mathrm{M}$. Because equivalent levels of binding to the heptamer site alone require a $10^{3}$-fold higher protein concentration (Fig. 1B), the association constant for this site can be estimated to be on the order of $10^{5}-10^{6} / \mathrm{M}$. Equivalent levels of binding of the protein to the heptamer site when adjacent to an occupied octamer site can be detected at a protein concentration $\sim 10$-fold higher than that necessary to bind to the octamer site. Thus, cooperative interactions between the PAOct- 2 proteins bound to the heptamer and octamer sites must account for the 50 - to 100 -fold higher affinity. This is likely an overestimate of the cooperativity, because the low affinity of the protein for binding to the single heptamer site may result in an underestimate of the level of this complex by the gel shift assay.

The results shown in Figure 1 were not analyzed in a more quantitative fashion because even at the highest protein concentrations, a significant fraction of the $\mathrm{H}^{+} \mathrm{O}^{+}$probe was recovered in the $\mathrm{B} 1$ complex. This suggests that there is a limitation in the binding assay that prevents quantitation of complex B2, the complex with both the heptamer and octamer sites occupied. This limitation may reflect dissociation of the protein from the heptamer site during the gel assay. Alternatively, it may reflect dissociation of the protein from the heptamer site in solution because we have also been unable to generate a complete protection of the heptamer site in a DNase I footprinting experiment. The same limitation may also be present in the detection of the protein-heptamer complex with the $\mathrm{H}^{+} \Delta \mathrm{O}$ probe. Although the quantitation of the results may be qualified, the binding is cooperative. This conclusion is strengthened by the coopera- 


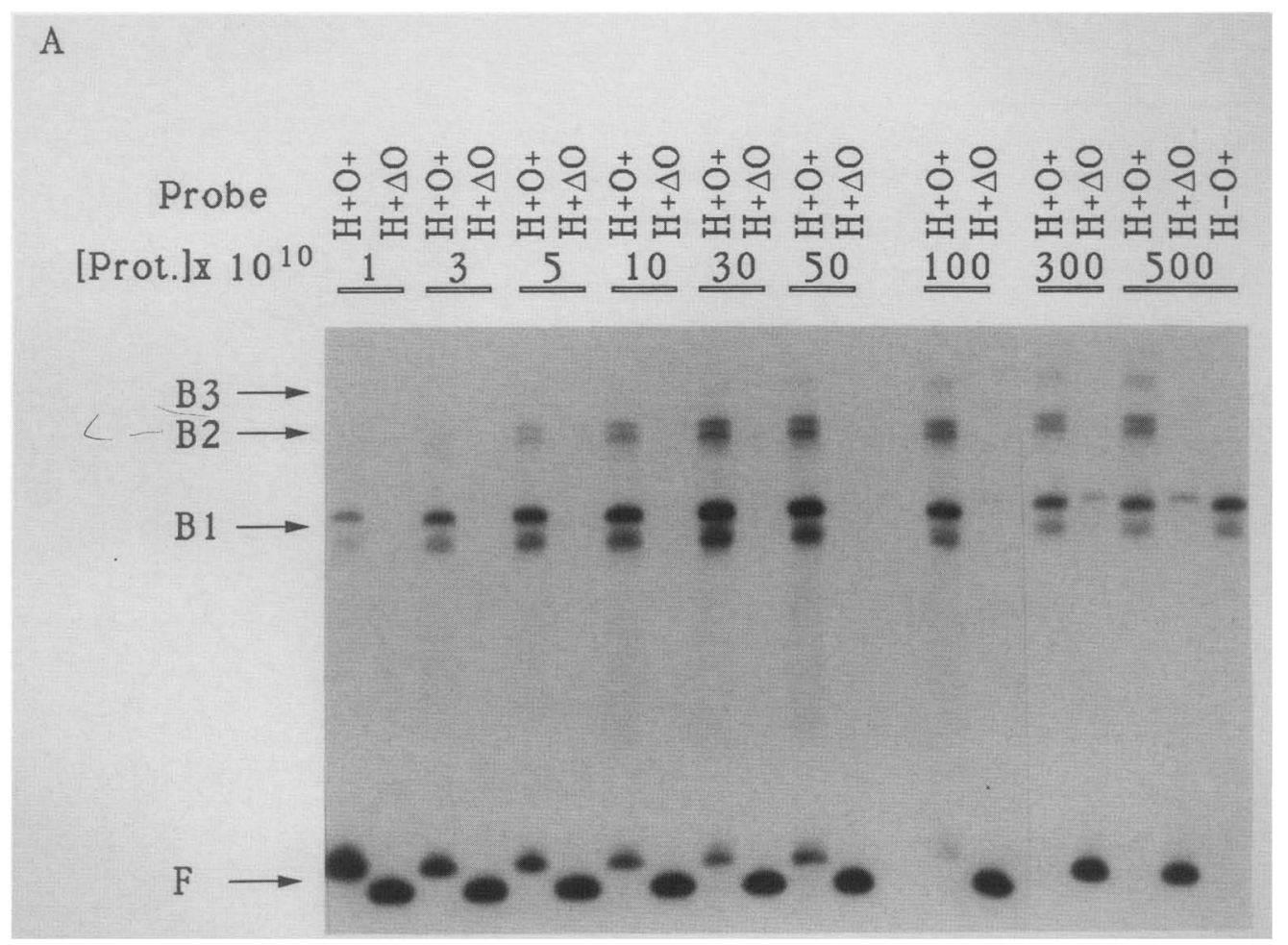

B

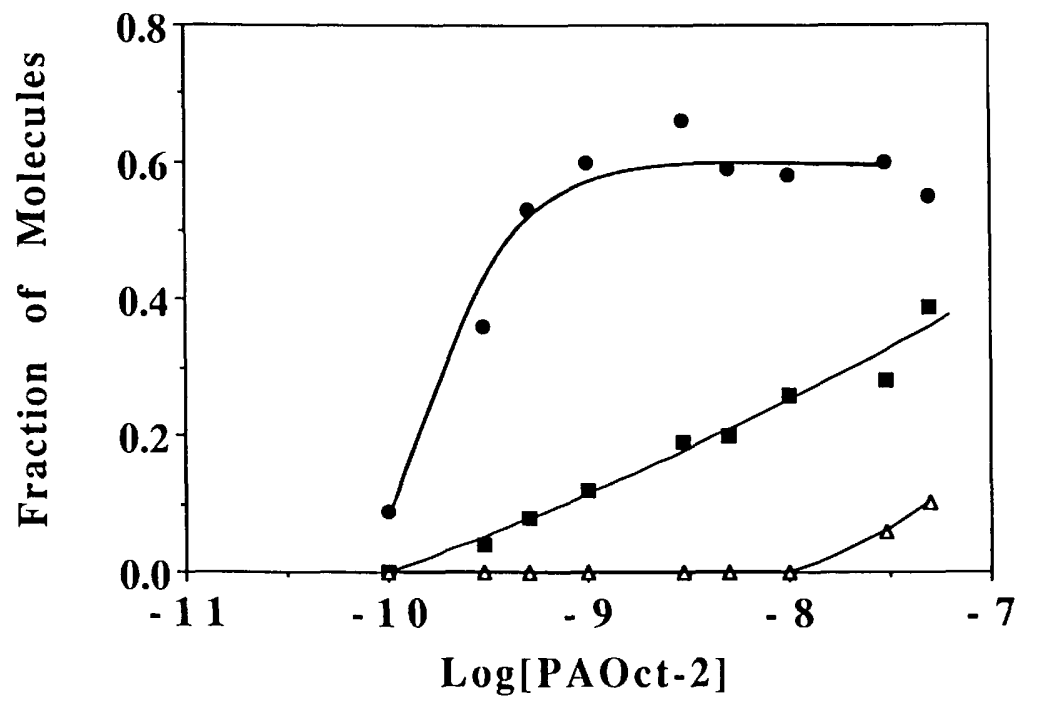

Figure 1. (A) Titration of PAOct-2 with probes $\mathrm{H}^{+} \mathrm{O}^{+}$and $\mathrm{H}^{+} \Delta \mathrm{O}$ (Table 1 ). Reactions were assembled and electrophoresed as described in Materials and methods. Concentrations of purified PAOct- 2 added to each reaction are indicated. Complexes representing singly liganded probe (B1) and doubly liganded probe (B2) are indicated (arrows), as is a complex designated $B 3$. Free probe $(F)$ is also indicated (arrow). (B) Plot of fractional occupancy of heptamer site against log protein concentration. Data points for this plot were obtained from a densitometric scan of the experiment depicted in A (LKB Ultrascan XL densitometer). Fraction of $\mathrm{H}^{+} \mathrm{O}^{+}$probe in complex $\mathrm{B} 2$ was calculated from the optical density as $\mathrm{B} 2 /(\mathrm{F}+\mathrm{B} 1+\mathrm{B} 2+\mathrm{B} 3)$. Fractional occupancy of the heptamer site for the $\mathrm{H}^{+} \Delta \mathrm{O}$ probe was calculated as B1/(F + B1). (a) Occupancy of the heptamer site in the $\mathrm{H}^{+} \mathrm{O}^{+}$probe (complex B2); $(\Delta)$ occupancy of the heptamer site in the $\mathrm{H}^{+} \Delta \mathrm{O}$ probe; $(\bullet)$ for comparison, the fraction of probe $\mathrm{H}^{+} \mathrm{O}^{+}$in complex $\mathrm{Bl}$. tive binding of the protein to a probe containing two octamer sites (see below).

\section{Methylation interference analysis of PAOct-2 binding to heptamer site}

Methylation interference data for the PAOct-2-heptamer complex and complexes B1 and B2 are shown in Figure 2. The pattern of interference over the heptamer site is almost symmetric for the heptamer complex. The heptamer sequence, together with the adjacent guanine res- idue from the immunoglobulin promoter, constitutes an 8-nucleotide sequence with dyad symmetry: CTCATGAG. This symmetry is probably fortuitous, as it is not a conserved feature of the heptamer sequence in immunoglobulin promoters. The two guanine residues on each strand of this sequence as well as one additional guanine residue, interfere with binding when methylated (Fig. 2A). Interaction of PAOct-2 with the octamer site is not symmetric with five sites on one strand and with one site on the other strand showing strong interferences (Fig. 2B). The affinity of the PAOct-2 protein for 
A

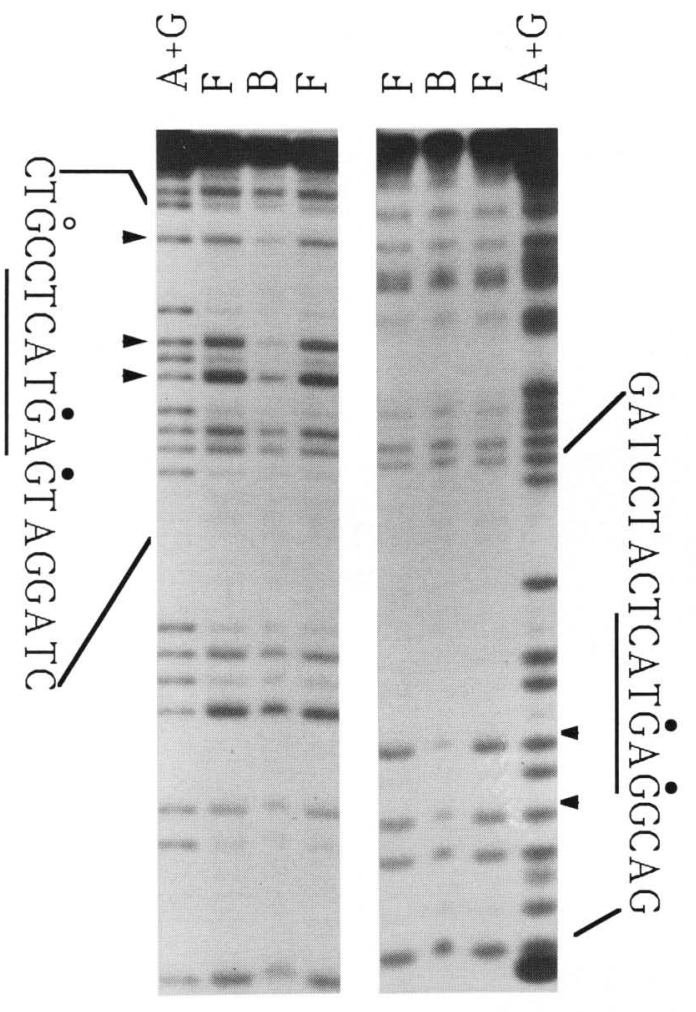

C

B

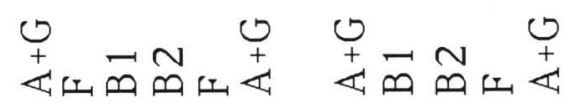
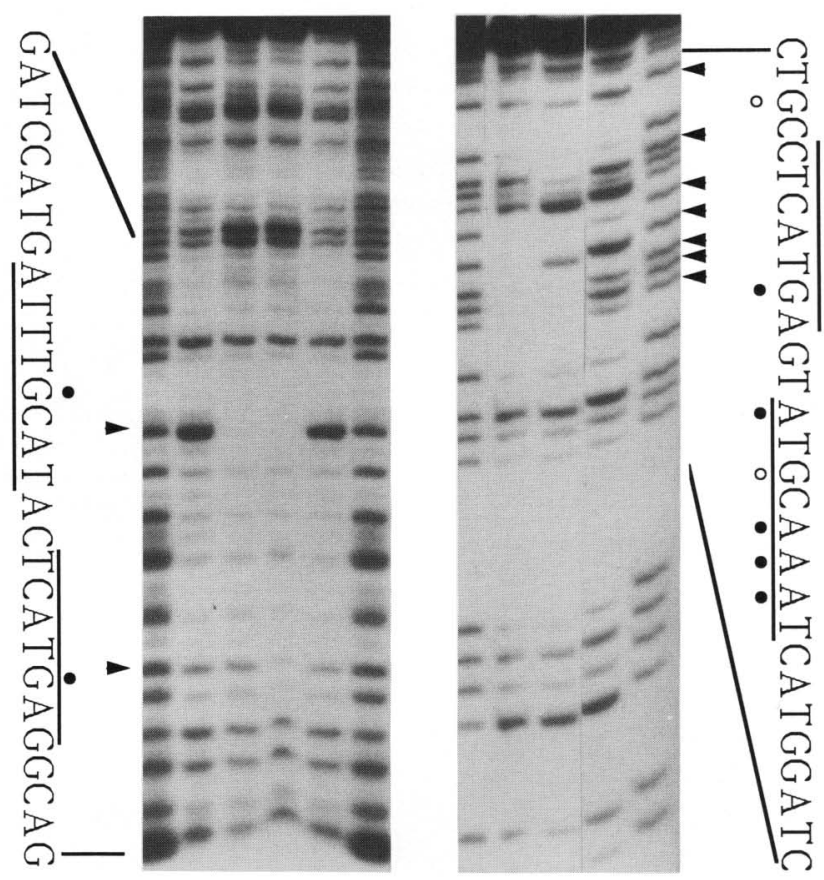

Figure 2. (A) Methylation interference analysis for binding of PAOct-2 to the $\mathrm{H}^{+} \Delta \mathrm{O}$ probe. Methylation interference analysis was carried out as described in Materials and methods. Lanes from a DNA sequencing gel are shown. (Left) The four lanes are derived from probe labeled at the HindIII end; (right) the four lanes are derived from probe labeled at the $E c o$ RI end. (Lanes $A+G$ ) Reference ladders of cleavages at A and $\mathrm{G}$ residues; (lanes $F$ ) the cleavage pattern of free DNA; (lanes $B$ ) the cleavage pattern of DNA isolated from the bound complex. The relevant sequences are aligned with the $A+G$ ladders. Arrowheads indicate the position of interfering residues denoted on the adjacent sequence by $\bullet$ (strong interferences) or $O$ (weak interferences). (B) Methylation interference analysis for binding of PAOct- 2 to the $\mathrm{H}^{+} \mathrm{O}^{+}$probe. Methylation interference analysis was carried out as described above. (Left) The six lanes are derived from probe labeled at the EcoRI end; and (right) the five lanes are derived from probe labeled at the HindIII end. (Lanes B1) The cleavage pattern of DNA isolated from the singly liganded complex, (lanes $B 2$ ) the cleavage pattern of DNA isolated from the doubly liganded complex. The relevant sequences are aligned with the $A+G$ ladders. Arrowheads indicate the position of interfering residues in the B2 complex denoted on the adjacent sequence by $\bullet$ (strong interferences) or $O$ (weak interferences). $(C)$ Summary of methylation interference contacts for probe $\mathrm{H}^{+} \mathrm{O}^{+}$complexes $\mathrm{B} 1$ and $\mathrm{B} 2$ and for probe $\mathrm{H}^{+} \Delta \mathrm{O}$ complex $\mathrm{B} 1$.

pancy of the octamer and heptamer sites, has the same methylation interference pattern observed for complex B1 but with one additional site on each strand where methylation of guanine interferes with binding (Fig. 2B). However, when the methylation interference contacts for the heptamer site complex, octamer site complex

these two sites differs by 1000 -fold. Given this weak binding to the heptamer site, the interaction of PAOct-2 with the heptamer sequence may be more sensitive to modifications that only slightly reduce the binding affinity.

The complex B2, representing simultaneous occu- 
(B1), and for the simultaneous occupancy of the two sites (B2) are compared, it is apparent that all of the contacts found in the individual complexes are not maintained in the B2 complex (Fig. 2C). Specifically, there are two guanines in the heptamer site where methylation interferes with binding that is not detected in analysis of the $\mathrm{B} 2$ complex and a strong interference at a guanine residue in the octamer site becomes weaker in complex B2. The loss of detection of interference at these sites may reflect an alternate conformation of binding by the protein in the doubly liganded complex or may reflect the increased stability of these protein-DNA complexes due to cooperative interaction of the adjacent protein molecules.

\section{The Oct-2 POU domain is sufficient for cooperative binding to adjacent heptamer and octamer sites}

Having established that the PAOct- 2 protein bound cooperatively to the heptamer and octamer sites, it was important to rule out the possibility that protein A sequences in the fusion protein mediated the cooperative interaction. This was accomplished by assaying truncated forms of the Oct- 2 protein synthesized in vitro from RNAs transcribed from the Oct-2 cDNA (Fig. 3). The Oct-2 protein, designated $\mathrm{P}-\mathrm{H}-\mathrm{C}$, extends from the POU box through the POU homeo box to the carboxyl terminus of the protein. This protein shares the same segment of the oct-2-coding sequences with PAOct-2. When assayed by mobility shift assay, P-H-C /which contained residues spanning the POU box; the POU homeo box; through the carboxyl terminus) produced Bl

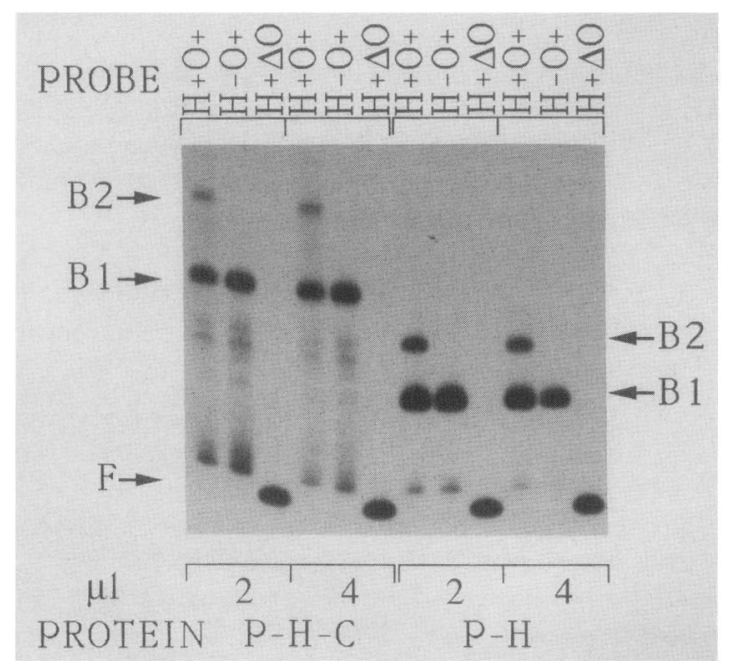

Figure 3. Gel mobility shift assay with truncated forms of Oct- 2 synthesized by translation in vitro. DNA-binding reactions were assembled as described in Materials and methods. In vitro translations were carried out as described in Materials and methods. Two or four microliters of the indicated in vitro translated protein (P-H-C or P-H, for details, see Materials and methods) were assayed with the indicated probe. Complexes representing singly liganded (B1) or doubly liganded (B2) probe are indicated by arrows. Free probe $(\mathrm{F})$ is shown (arrow). and $\mathrm{B} 2$ complexes with the $\mathrm{H}^{+} \mathrm{O}^{+}$probe. Formation of complex $\mathrm{B} 2$ depended on the presence of the intact heptamer site because it was not detected with the $\mathrm{H}^{-} \mathrm{O}^{+}$ probe. Furthermore, no complex was detected with the $\mathrm{H}^{+} \Delta \mathrm{O}$ probe, indicating that at the protein concentrations assayed, $\mathrm{P}-\mathrm{H}-\mathrm{C}$ was capable of occupying the heptamer site only when the adjacent octamer site was occupied. Therefore, Oct-2 sequences contained within P-H-C specify cooperative binding to the heptamer site.

To determine whether Oct-2 protein sequences downstream of the POU homeo domain were required for the cooperative interaction, an additional protein synthesized in vitro was assayed. $\mathrm{P}-\mathrm{H}$, a protein of 157 amino acid residues, contains only the POU box and POU homeo box of the Oct- 2 protein. When assayed in the mobility shift assay with the three probes described above, this protein behaved identically to $\mathrm{P}-\mathrm{H}-\mathrm{C}$ : Formation of complex $\mathrm{B} 1$ and $\mathrm{B} 2$ was observed with the $\mathrm{H}^{+} \mathrm{O}^{+}$ probe, formation of only complex B1 was observed with the $\mathrm{H}^{-} \mathrm{O}^{+}$probe, and no complex was detected with $\mathrm{H}^{+} \Delta \mathrm{O}$ probe. Therefore, the POU box and POU homeo box are sufficient to allow cooperative binding of Oct-2 to adjacent octamer and heptamer sites.

\section{Binding of PAOct-2 to adjacent octamer sites}

Is the heptamer site simply a low-affinity octamer site? As it was difficult to align the heptamer sequence with the octamer sequence, we wondered whether the heptamer site was contacted by a distinct DNA-binding domain of the Oct- 2 protein. Cooperative binding by the Oct- 2 protein could be dependent on the presence of this unique site adjacent to an octamer site. Alternatively, the cooperative interactions could reflect an inherent property of the Oct- 2 protein; thus, substitution of a second octamer site for the heptamer site should also yield cooperative binding. Four probes were used to test the possibility that Oct- 2 could bind to two adjacent octamer sites cooperatively (Fig. 5). Probes $2 \mathrm{xOA}, 2 \mathrm{xOB}$, and $2 \mathrm{xOD}$ (Table 1) contained the three possible orientations of two octamer sites separated by 2 nucleotides (as are heptamer and octamer in $\mathrm{H}^{+} \mathrm{O}^{+}$. Probe $2 \mathrm{xOC}$ contained two octamer sites in inverted orientation with a 2-nucleotide overlap. This probe was designed to test the possibility that the consensus heptamer site represented an overlapping $5 / 8$ match with the octamer site (cf. probes $\mathrm{H}^{+} \mathrm{O}^{+}$and $2 \mathrm{xOC}$ in Table 1). Titrations of PAOct-2 with the four probes indicated that probes $2 \mathrm{xOA}$ and $2 \mathrm{xOD}$ formed doubly liganded complexes at relatively low protein concentrations (Fig. 4). Probes $2 \mathrm{xOB}$ and $2 \mathrm{xOC}$ proved refractory to formation of doubly liganded complexes (Fig. 4), except at very high protein concentrations. Identical results were obtained with the in vitro-translated Oct-2 $\mathrm{P}-\mathrm{H}-\mathrm{C}$ protein (data not shown). Confirmation that the complexes labeled B2 were, in fact, doubly liganded complexes was provided by copper/phenanthroline footprinting, which revealed that both octamer sites in probes $2 \mathrm{xOA}$ (Fig. $5 \mathrm{~A}$ ) and $2 \mathrm{xOD}$ (data not shown) were occupied. Additionally, an experiment where two different molecular-weight 


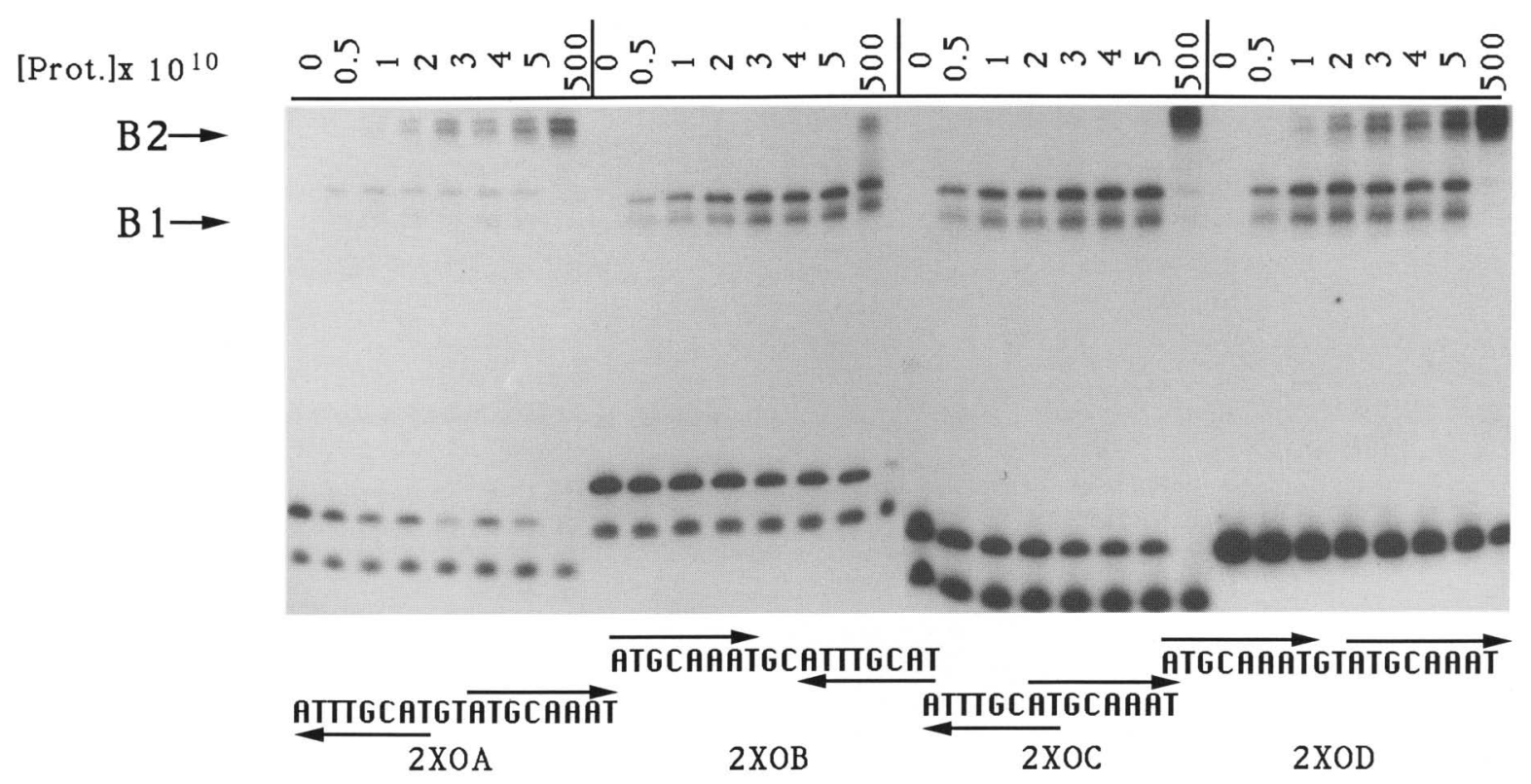

Figure 4. Titrations of PAOct-2 with four probes containing different orientations of two octamer sites. DNA-binding reactions were assembled and complexes resolved as described in Materials and methods. Reactions contained the indicated concentrations of protein, and the probes are depicted below the relevant titration. Complexes representing singly liganded (B1) and doubly liganded (B2) probe are indicated by arrows. The species that migrates below some of the free probes is believed to be single-stranded DNA and clearly does not titrate. In quantitative experiments (Fig. 6) this band was therefore not quantitated with free probe.

Oct-2-related proteins were mixed confirmed that twoprotein molecules were present in the B2 complexes (data not shown). Finally, the B2 complexes formed with probes $2 \mathrm{xOB}$ and $2 \mathrm{xOC}$ are likely to represent specific doubly liganded complexes, because an equivalent amount of protein did not yield a second complex when assayed on probe $\mathrm{H}^{-} \mathrm{O}^{+}$(see Fig. 1A).

Examination of DNase I and copper/phenanthroline footprints of the PAOct- 2 octamer site complex reveals an assymetric protection that extends $3^{\prime}$ further of the octamer sequence than $5^{\prime}$ (Fig. 5A). This assymetry predicts that when two octamer sites are oriented in a convergent pattern (2xOB probe), occupation of both sites necessitates considerable overlap of the footprints (Fig. $5 B)$. On the other hand, when the sites are oriented in a divergent pattern (2xOA probe), occupation of both sites requires a minimal overlap of the footprints (Fig. 5B). The parallel orientation of probe $2 \mathrm{xOD}$ falls somewhere between these two extremes (some overlap of the footprints would be expected). The difficulty in generating a doubly liganded complex on probe $2 \mathrm{xOB}$ is consistent with a steric hindrance, due to an extensive overlap of the binding sites.

\section{Quantitative analysis of cooperative binding to adjacent octamer sites}

Probes $2 \mathrm{xOA}$ and $2 \mathrm{xOD}$ were readily capable of forming doubly liganded complexes. Quantitative analysis of the binding of PAOct-2 protein to these two probes was performed on titration data over the entire range of the transition. This analysis makes the assumption that the gel shift assay accurately reports the fraction of molecules in the unbound, singly bound, and doubly bound forms. The titration curves for the interaction of PAOct2 and probe $2 \mathrm{xOA}$ are shown in Figure 6A. The data were analyzed subject to the constraint that the microscopic binding constants describing the interaction of protein with either site in the probe are identical $\left(k_{1}=k_{2}\right.$; see Materials and methods). Copper/phenanthroline footprint analysis of singly liganded DNA complex B1 showed no apparent bias toward occupancy of either site in probe $2 \mathrm{xOA}$, in agreement with the above constraint (Fig. 5A). This constraint allows the determination of $k_{1}$ and $k_{12}$, the cooperativity constant, from the binding titration of probes with two sites (M. Brenowitz, unpubl. numerical analysis). The agreement of the curves predicted by the best-fit binding constants (Table 2) with the data points over the entire range of the titration suggests that this model is adequate to describe the results. This quantitative analysis indicates that binding of PAOct-2 to the two adjacent octamer sites in $2 \mathrm{xOA}$ occurs with $\sim 10$-fold cooperativity (Table 2 ).

Binding of PAOct-2 to a probe containing a single octamer site (probe $\mathrm{H}^{-} \mathrm{O}^{+}$) was analyzed quantitatively also (Fig. 6B). The value of $k_{1}$ determined from this experiment was identical, within experimental error, to that determined from probe $2 \mathrm{xOA}$ (Table 2). As another, but related, test of the validity of the model of cooperative interactions of protein binding to two identical octamer sites, values for $k_{1}$ and $k_{12}$ can be determined by simultaneous analysis of total data from both the singlesite probe experiment and the $2 \mathrm{xOA}$ probe experiment (Brenowitz et al. 1986; Senear et al. 1986). The results of 

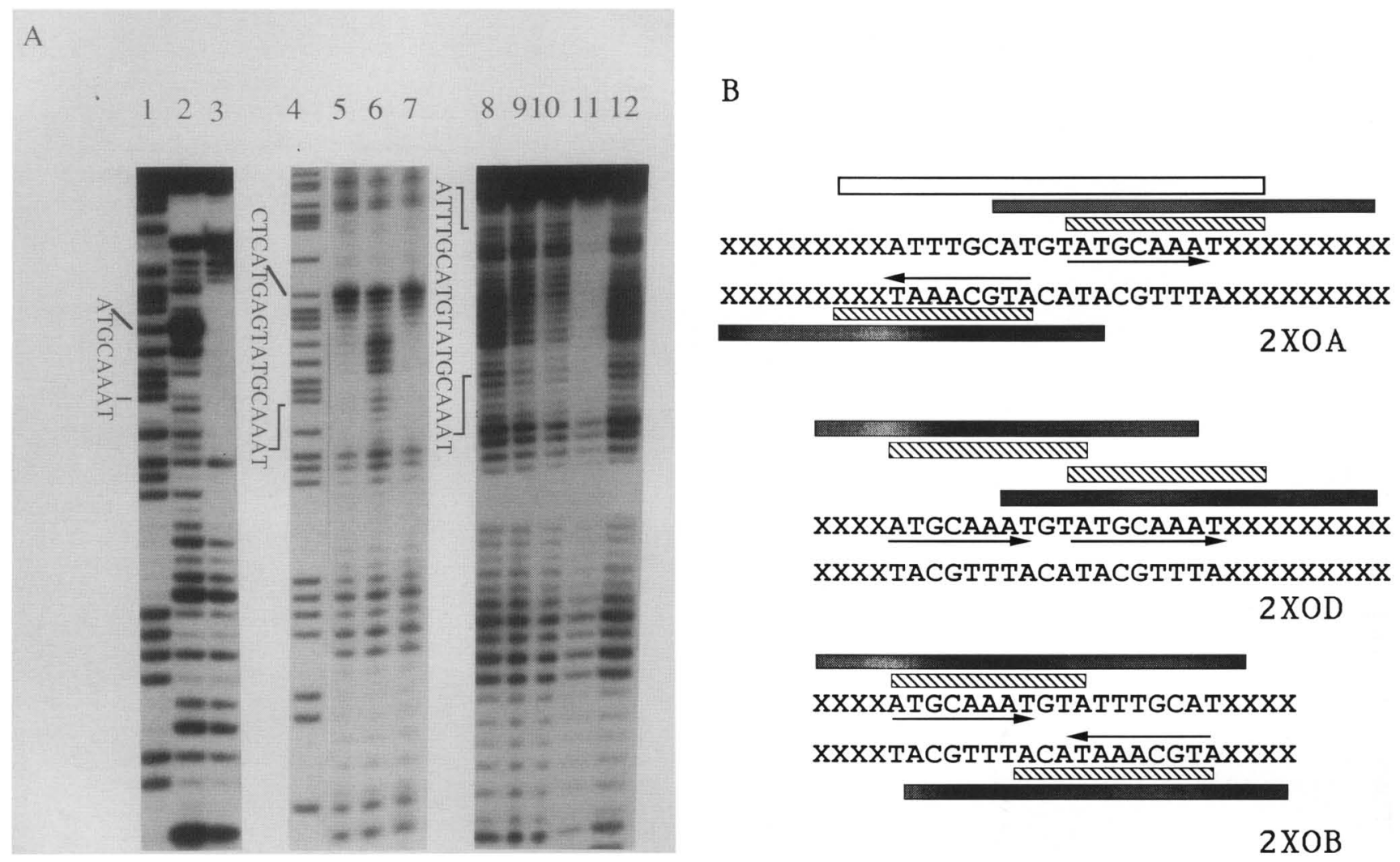

XXXXTACGTTTACATACGTTTAXXXXXXXXX $2 \mathrm{XOD}$

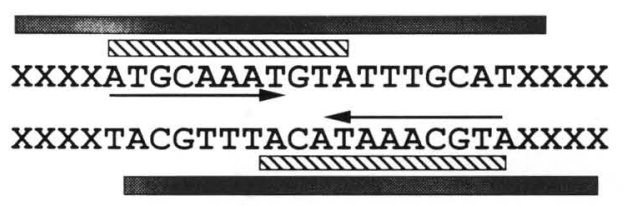

$2 \mathrm{XOB}$

Figure 5. (A) Footprint analysis of PAOct-2 complexes representing singly and doubly liganded probe. DNase I and copper/phenanthroline footprinting were performed as described in Materials and methods. Lanes from a DNA sequencing gel are depicted. (Lanes 1-3) DNase I footprint of PAOct-2 on the $\mathrm{H}^{-} \mathrm{O}^{+}$probe labeled at the HindIII end (Materials and methods; Table 1). (Lane 1) Reference $A+G$ ladder; (lane 2) DNase I cleavage pattern in the absence of protein; (lane 3) DNase I cleavage pattern in the presence of $50 \mathrm{nM}$ PAOct-2. (Lanes 4-7) In situ copper/phenanthroline cleavage pattern of singly and doubly liganded complexes of PAOct-2 with the $\mathrm{H}^{+} \mathrm{O}^{+}$probe, which was labeled at the HindIII end. The other terminus of the probe was an AseI site at position 576 in the vector sequence. (Lane 4) Reference A + G cleavage ladder; (lane 5) in situ cleavage pattern of the singly liganded complex (B1); (lane 6) in situ cleavage pattern of free probe; (lane 7 ) in situ cleavage pattern of the doubly liganded complex (B2). Note the absence of protection over the heptamer site. (Lanes 8-12) In situ copper/phenanthroline cleavage pattern of singly and doubly liganded complexes with the $2 x O A$ probe. (Lanes 8-12) In situ cleavage pattern of free probe; (lanes 9 and 10) in situ cleavage pattern of singly liganded complexes generated by the faster and slower mobility species of PAOct-2, respectively; (lane 11) in situ cleavage pattern of the doubly liganded complex (B2). Relevant DNA sequences are aligned with each set of experiments. (B) Schematic diagram depicting expected DNase I and copper/phenanthroline footprints on three of the probes with two octamer sites: $2 x O A, 2 x O D$, and $2 \times O B$. The hypothetical footprints are extrapolations from the footprint data for occupancy of a single site shown in $A$. The actual footprint of the doubly liganded complex with probe $2 \mathrm{xOA}$ is displayed for comparison. (Crosshatched bars) Copper/phenanthroline footprints; (dark stippled bars) DNase I footprints. The actual footprint of the doubly liganded $2 \mathrm{xOA}$ probe is shown (open bar).

this analysis are completely consistent with the analysis of each probe alone (Table 2) and support the conclusion that Oct-2 binding to two adjacent octamer sites show 10-fold cooperativity.

A similar analysis was performed with the data from titrations with probe $2 \mathrm{xOD}$ (data not shown). In this case, the two octamer sites are aligned in parallel with a spacing of 2 nucleotides. The results in Figure 4 show that both sites in probe $2 \mathrm{XOD}$ can be occupied by the protein at reasonably low concentrations. Quantitative analysis of the data using a pool of two titrations yields a value of $1.3 \pm 0.6$ for $k_{12}$, the cooperativity parameter (Table 2, see Materials and methods). This result suggests that the two proteins bind with little or no cooper- ativity to two sites in parallel alignment spaced by 2 nucleotides.

Titrations of the binding of the P-H form of the Oct-2 protein to the probe $2 \mathrm{xOA}$ with divergent octamer sites were also analyzed. The absolute concentration of $\mathrm{P}-\mathrm{H}$ protein was not known in this titration because the binding material was synthesized by translation in vitro. Thus, relative values of the concentration of $\mathrm{P}-\mathrm{H}$ were used in analysis of the titration curves, and a value for $k_{12}$ was determined (Fig. 6C). The value of $k_{12}$ obtained from this analysis, $4.3 \pm 1.5$, is lower than that reported above for PAOct-2. However, given that P-H clearly binds cooperatively to the $\mathrm{H}^{+} \mathrm{O}^{+}$probe, this result suggests that the $\mathrm{P}-\mathrm{H}$ protein also binds cooperatively to 
A

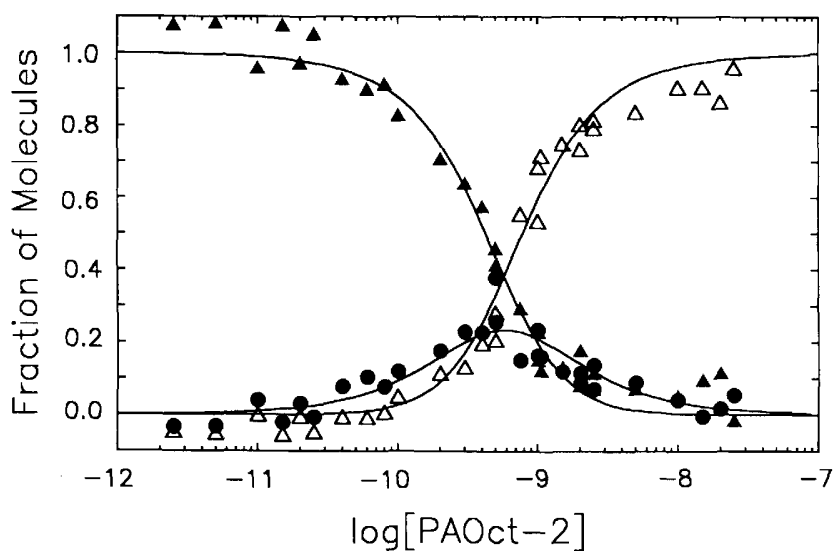

\section{C}

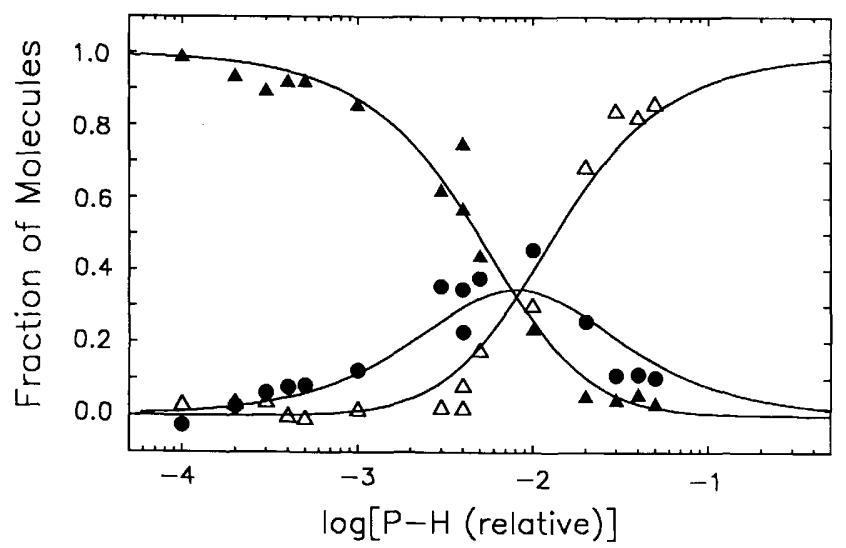

B

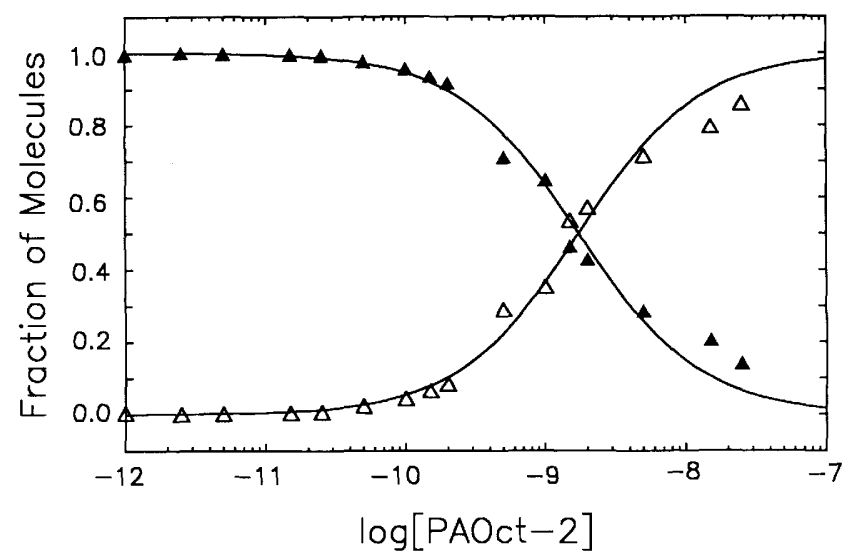

Figure 6. (A) Titration curves for a gel mobility shift experiment for PAOct- 2 binding to probe $2 \mathrm{xOA}$. DNA-binding reactions were assembled and complexes were resolved as described in Materials and methods. Quantitative analysis was performed as described (see Materials and methods; Brenowitz and Senear 1989). (A) Free probe; $\{\bullet$ singly liganded probe $(\mathrm{B} 1) ;\langle\Delta|$ doubly liganded probe (B2). Curves represent titration curves based on the parameters obtained from the best fit of the data to equations $\mathrm{la}-\mathrm{c}$ (see $\mathrm{Ma}$ terials and methods). (B) Titration curves for a gel mobility shift experiment for PAOct-2 binding to probe $\mathrm{H}^{-} \mathrm{O}^{+}$. DNA-binding reactions were assembled and complexes were resolved as described in Materials and methods. Quantitative analysis was performed as described (see Materials and methods; Brenowitz and Senear 1989). (A) Free probe; $(\Delta)$ liganded probe (B1). Curves represent titration curves based on the parameters obtained from the best fit of the data to equations $2 \mathrm{a}$ and $\mathrm{b}$ (see Materials and methods). (C) Titration curves for a gel mobility shift experiment for in vitro transcribed $\mathrm{P}-\mathrm{H}$ binding to probe $2 \mathrm{xOA}$. DNA-binding reactions were assembled and complexes were resolved as described in Materials and methods. Quantitative analysis was performed as described (see Materials and methods; Brenowitz and Senear 1989). $(\Delta)$ Free probe; $(\bullet)$ singly liganded probe $(\mathrm{B} 1) ;(\Delta)$ doubly liganded probe $(\mathrm{B} 2)$. Curves represent titration curves based on the parameters obtained from the best fit of the data to equations $1 \mathrm{a}-\mathrm{c}$ (see Materials and methods).

two octamer sites when they are in a divergent orientation.

\section{Discussion}

The major transcriptional determinant in the immunoglobulin promoter is the octamer site that is recognized by the B-cell-specific protein Oct-2 (Dreyfus et al. 1987; Wirth et al. 1987). Promoters of immunoglobulin heavy chain genes also have a conserved heptamer sequence, spaced either 2, 14, or 22 bp upstream of the octamer site (Ballard and Bothwell 1986; Eaton and Calame 1987). Mutation of this conserved sequence reduced three- to fivefold the level of transcription from the promoter in B cells (Eaton and Calame 1987). We demonstrated that a protein synthesized in Escherichia coli from a plasmid containing part of the Oct- 2 cDNA binds specifically to the heptamer site, even though this sequence is not closely related to the octamer sequence. Furthermore, the Oct-2-related protein interacts cooperatively when bound to both the octamer and heptamer sites and thus increases the occupancy of the heptamer site by $\sim 50$ to 100 -fold. The presence of the heptamer site greatly expands the concentration range over which the heavy chain promoter is sensitive to levels of Oct-2. At low Oct- 2 concentrations, the octamer site alone would be partially occupied. As this site becomes occupied with increasing Oct- 2 concentration, a second molecule of Oct- 2 would bind to the heptamer site. The binding of this second molecule would account for the observed three- to fivefold dependence of transcription on the

Table 2. Binding constants for PAOct-2 binding to octameroctamer probe

\begin{tabular}{lrr}
\hline Probe & \multicolumn{1}{c}{$k_{1} / \mathrm{M}$} & \multicolumn{1}{c}{$k_{12}$} \\
\hline $\mathrm{H}^{-} \mathrm{O}^{+}$ & $5.8 \pm 1.0 \times 10^{8}$ & - \\
$2 \mathrm{xOA}$ & $5.3 \pm 1.1 \times 10^{8}$ & $10.7 \pm 3.4$ \\
Simultaneous $^{\mathrm{a}}$ & $5.4 \pm 1.0 \times 10^{8}$ & $10.2 \pm 3.5$ \\
$2 \mathrm{xOD}$ & $18.1 \pm 5.0 \times 10^{8}$ & $1.3 \pm 0.6$ \\
\hline
\end{tabular}

a Simultaneous analysis of the two probes $\mathrm{H}^{-} \mathrm{O}^{+}$and $2 \mathrm{xOA}$. 
heptamer sequence. This increase in transcription, due to binding to the heptamer site, could potentially be greater in some cells, as it is not clear that the B-cell tumor lines that were tested for heptamer activity express adequate concentrations of Oct- 2 to saturate the heptamer site (Eaton and Calame 1987).

Oct-2-derived proteins containing only the POU domains are fully active in binding to the octamer site and in cooperatively binding to the heptamer site. This $162-$ amino-acid sequence contains two evolutionary conserved regions, the POU box and POU homeo box (Clerc et al. 1988; Herr et al. 1988; Sturm et al. 1988). Because the sequence of the heptamer site does not closely resemble the octamer site, it was possible that the POU box specified two distinct DNA sequence recognition surfaces. We do not believe this is the case but rather propose that the same protein surface is responsible for recognition of both the octamer and heptamer sites. A DNA probe containing two prototype octamer sites, oriented in a divergent pattern and spaced by 2 nucleotides, also binds the Oct-2-related protein in a cooperative fashion. The degree of cooperativity is 10 -fold. These results suggest that the heptamer sequence in the heavy chain gene is conserved as an intermediate affinity Oct-2-binding site so that the promoter responds to a broader range of levels of the B-cell-specific protein.

It is interesting to picture two Oct- 2 proteins bound to two octamer sites, spaced by $2 \mathrm{bp}$ oriented in a divergent pattern. In this configuration, the copper/phenanthroline footprints of the two proteins abut precisely, and the proteins should be aligned on the same side of the duplex helix and related by an approximate twofold center of rotation. Binding to the two octamer sites in this divergent configuration was clearly cooperative. Cooperative interactions between Oct- 2 proteins bound to octamer sites with spacings of 14 and 22 bp would also be expected because the heptamer and octamer sites are separated by these distances in some immunoglobulin promoters. Interestingly, the relative orientations of the heptamer and octamer sites are conserved in all heavychain promoters examined, suggesting that this orientation may be essential for cooperative binding. Two octamer sites oriented in a parallel fashion and spaced by 2 bp can also bind Oct- 2 proteins simultaneously. In this case, the binding is apparently noncooperative. This is somewhat surprising, as the copper/phenanthroline footprints should overlap by $1 \mathrm{bp}$ in this orientation. It is possible that a potential steric hindrance due to this overlap is compensated by positive cooperative interactions. If this were the case, parallel binding sites with other spacings may display cooperative binding. However, this would also infer that two Oct-2 proteins could cooperatively interact in two different relative orientations. Competitive binding for the two octamer sites was clearly observed when two octamer sites were convergently oriented and spaced by 2 nucleotides. This was not unexpected, as the asymmetric footprints would have to overlap extensively when two proteins bind to this probe simultaneously.
Cooperative binding to two octamer sites also only requires protein sequences within the POU domain. The ability to specifically recognize another protein bound to adjacent sequences may reflect the function of the POU box within the POU domain. The other region within the POU domain, the homeo box, is clearly involved in DNA binding and must make direct contacts with the major groove of the binding site. The POU box, on the other hand, is not essential for specific DNA binding, because one of the original Oct-2 cDNA clones, isolated on the basis of binding to the octamer site, contained less than half of the POU box. However, the POU box is important for DNA binding, because deletions or mutations of this region significantly lower the affinity of Oct- 2 for the octamer site. There are several indications that proteins possessing the POU domain interact cooperatively with other proteins. First, it is highly likely that Oct-1, as well as Oct-2, binds cooperatively to the heptamer-octamer pair of sites (Poellinger and Roeder 1989). Second, the Oct-1 protein is thought to interact with the herpes simplex virus virion protein $\alpha \mathrm{TIF}$ (ICP25/VP16/VMW65) and another cellular protein in cooperatively binding and regulating the immediate early promoters of the virus (Gerster and Roeder 1988; T.M. Kristie et al., in prep.). These types of cooperative interactions have not been described for previously characterized proteins containing homeo box domains and thus may reflect the contribution of the POU box.

Perhaps the best-characterized system displaying cooperative interactions is the binding of bacteriophage $\lambda c \mathrm{I}$ repressor protein to the operators $\mathrm{O}_{R} 1, \mathrm{O}_{R} 2$, and $\mathrm{O}_{R} 3$ of the $\lambda P_{R}$ promoter (Johnson et al. 1979). This system is highly cooperative with values for the cooperativity constants reported $\sim 26$ (Ackers et al. 1982). Interestingly, although the physiologically relevant configuration of $c$ I-binding sites is one where the sites are adjacent, when two operator sites are separated by six helical turns, i.e., $60 \mathrm{bp}$, cooperative binding of $c$ I repressor to the two sites is still observed (Hochschild and Ptashne 1986). This cooperative interaction presumably occurs via a looping of the DNA.

Regulation of gene expression through the cooperative interaction of DNA-binding proteins also has been observed with mammalian proteins (Topol et al. 1985; Davidson et al. 1988; Tsai et al. 1989). The ability of Oct-2 molecules to interact cooperatively when binding to octamer sites may account for the observed synergistic transcriptional activity of the immunoglobulin heavychain promoter and enhancer (Garcia et al. 1986). Protein-protein interactions, via DNA looping, between Oct- 2 molecules bound to the octamer site in the heavychain enhancer and the octamer and heptamer sites in the heavy-chain promoter would bring the enhancer more stably into close proximity with the promoter. This, in turn, might enhance the ability of factors bound to the enhancer to interact with general transcription factors on the promoter. Currently we are examining the possibility that Oct-2 can bind to octamer sites separated by large distances through a looping mechanism. 


\section{Materials and methods}

\section{Plasmids and constructions}

Plasmid 3-1 contained the 1.1-kb cDNA fragment with EcoRI termini isolated from a $\lambda$ gt $1 \mathrm{l}$ recombinant and ligated into the unique $E c o R I$ site of $\mathrm{pKS}^{+}$(Stratagene). The insert corresponded to nucleotide positions $655-1713$ in the oct-2-coding sequence (Clerc et al. 1988).

Plasmid pRIT2T (Pharmacia) is designed to give temperatureregulated overexpression of recombinant proteins resulting from fusion of coding sequence of interest downstream of the amino-terminal portion of the $S$. aureus protein-A gene. Plasmid oct- $2 / \mathrm{pRIT} 2 \mathrm{~T}$ was constructed by isolating the $1.1-\mathrm{kb}$ EcoRI fragment from plasmid 3-1, filling in the EcoRI termini with the Klenow fragment of DNA polymerase I (BoehringerMannheim), and ligating the resultant blunt-end fragment into the SmaI site of plasmid pRIT2T with T4 DNA ligase (Boehringer-Mannheim). The ligation mixture was transfected into $E$. coli strain $\mathrm{X} 90$, a lysogenic strain with $\mathrm{CI}^{+}$phenotype (gift of R. Sauer). Recombinants with an in-frame fusion with protein A were isolated. One such isolate was designated oct-2/ pRIT2T.

Plasmid pBS-ATG-oct-2 has been described previously /Clerc et al. 1988).

\section{DNA probes}

Complementary synthetic oligonucleotides with an EcoRI site compatible sequence on one strand and a BamHI compatible sequence on the other strand were annealed and ligated into pUC1 8 or pUC19, cut with EcoRI and BamHI. One exception to this is the oligonucleotide for probe $2 \mathrm{xOB}$, which is self-complementary with BamHI overhangs. This was cloned directly into the BamHI site of pUC19. The resultant series of plasmids were the source of DNA probes used in these studies and were excised by digestion with EcoRI and HindIII, except where noted. One strand of the oligonucleotide pairs and their designations are listed in Table 1.

\section{Induction and purification of PAOct-2}

The PAOct-2 fusion protein was purified from $E$. coli strain N4830-1 (F-, su-, his-, ilv-, galK $\Delta 8, \Delta($ chlD-pgl), $\lambda, \Delta \mathrm{Bam}, \mathrm{N}+$, cI857, $\Delta \mathrm{H1}$ ) (Pharmacia), harboring the plasmid oct-2/pRIT2T. A 150-liter culture of cells was grown in L broth, containing 1 $\mathrm{g} /$ liter of cerelose and $100 \mu \mathrm{g} / \mathrm{ml}$ of ampicillin in a New Brunswick fermentation fermentor at $30^{\circ} \mathrm{C}$. Cells were grown with forced aeration and agitation until the cell density reached $\sim 4 \times 10^{8}$ cells $\left./ \mathrm{ml} \quad \mathrm{OD}_{590}=1\right)$. The temperature then was shifted rapidly to $42^{\circ} \mathrm{C}$ to induce expression of the fusion protein. After $1 \mathrm{hr}$, cells were harvested in a continuous flow centrifuge, resuspended in Tris-sucrose $[50 \mathrm{~mm}$ Tris- $\mathrm{HCl}, 10 \%$ sucrose ( $\mathrm{pH} 8.0$ )] to a final $\mathrm{OD}_{590}$ of 200 , frozen in liquid nitrogen, and stored at $-70^{\circ} \mathrm{C}$.

Frozen cells were thawed at $4^{\circ} \mathrm{C}$ after dilution with an equal volume of Tris-sucrose. Phenylmethylsulfonyl fluoride (PMSF) was added to a final concentration of $1 \mathrm{mM}$ and 0.05 volumes of lysis solution [ $50 \mathrm{~mm}$ Tris- $\mathrm{HCl}(\mathrm{pH} 8.0], 0.3 \mathrm{~mm}$ spermidine$\mathrm{HCl}, 10 \%$ sucrose, $2 \mathrm{M} \mathrm{NaCl}, 5 \mathrm{mg} / \mathrm{ml}$ lysozyme] were added. After $45 \mathrm{~min}$ on ice, the cell suspension was incubated at $37^{\circ} \mathrm{C}$ for $5 \mathrm{~min}$. During this incubation, the cells were mixed by inversion every minute. $\mathrm{NaCl}$ was added to a final concentration of $0.5 \mathrm{M}$ and the lysed cell suspension was centrifuged for 60 $\mathrm{min}$ at $20,000 \mathrm{rpm}$ in a Sorvall SS-34 rotor. The supernatant from this step was dialyzed overnight against buffer TST [50 $\mathrm{mm}$ Tris- $\mathrm{HCl}(\mathrm{pH} \mathrm{7.6)}, 150 \mathrm{~mm} \mathrm{NaCl}, 0.05 \%$ Tween 20], con- taining $1 \mathrm{mM}$ PMSF. The dialyzed lysate was applied to an IgG Sepharose 6 fast flow column (Pharmacia) that was equilibrated with TST buffer. Then the column was washed sequentially with 10 column volumes of TST buffer plus PMSF and 2 column volumes of $5 \mathrm{~mm}$ ammonium acetate $(\mathrm{pH} 5.0)$. The PAOct-2 fusion protein was eluted with $0.5 \mathrm{M}$ acetic acid $(\mathrm{pH}$ 3.4). Fractions containing DNA-binding activity were pooled and dialyzed against buffer O $(1 / 2 \times$ TST buffer plus $10 \%$ glycerol, $1 \mathrm{~mm}$ dithiothreitol (DTT), and $1 \mathrm{mM}$ EDTA). This material was applied to a calf thymus DNA-cellulose column (Pharmacia) that had been equilibrated with buffer O. After loading, the column was washed with 5 column volumes of buffer $\mathrm{O}$, and the fusion protein was eluted with a linear gradient of $\mathrm{NaCl}$ from 75 to $500 \mathrm{~mm}$ in buffer $\mathrm{O}$.

\section{In vitro translations}

In vitro translations were performed in a rabbit reticulocyte lysate (Promega), according to the manufacturer's instructions. RNAs for the in vitro translation were transcribed from plasmid pBS-ATG-oct-2 (Clerc et al. 1988) with T3 RNA polymerase. The RNA template used to generate the protein species designated P-H-C was synthesized by transcribing StuI-linearized pBS-ATG-oct-2, yielding an RNA corresponding to positions 655-1446 of the oct-2-coding sequence. The protein species designated $\mathrm{P}-\mathrm{H}$ was produced from an RNA template transcribed from pBS-ATG-oct- 2 after it had been digested with PstI. This template corresponded to positions $655-1137$ of the oct-2-coding sequence.

\section{DNA-binding assays}

Reactions for gel mobility shift assays (Fried and Crothers 1981; Garner and Revzin 1981) were assembled at room temperature in a final volume of $15 \mu \mathrm{l}$ and contained $50 \mathrm{~mm}$ Tris- $\mathrm{HCl} / \mathrm{pH}$ 7.5), $60 \mathrm{~mm} \mathrm{NaCl}, 4 \%$ Ficoll, $1 \mathrm{~mm}$ DTT, $150 \mu \mathrm{g} / \mathrm{ml}$ bovine serum albumin, and $5 \times 10^{-10} \mathrm{M}$ DNA-binding-site probe. Nonspecific competitor DNAs used in the assays were 26 $\mu \mathrm{g} / \mathrm{ml}$ of poly(dIdC-dIdC) for assays of the purified PAOct-2 protein and a mixture of $25 \mu \mathrm{g} / \mathrm{ml}$ of sonicated denatured calf thymus DNA and $2.5 \mu \mathrm{g} / \mathrm{ml}$ of sonicated native calf thymus DNA for assays of in vitro synthesized proteins. Assays of in vitro synthesized protein also contained $1 \mathrm{~mm}$ EDTA. DNA probes were prepared as described (LeBowitz et al. 1988). Complexes were resolved on $4 \%$ (40:1 acrylamide/bis-acrylamide) native acrylamide gels, using a Tris-glycine buffer: $25 \mathrm{~mm}$ Tris, $190 \mathrm{~mm}$ glycine, $1 \mathrm{~mm}$ EDTA (pH 8.3).

Methylation interference assays were performed essentially as described (Kristie and Roizman 1988), with minor modifications. DNA probes were end-labeled at either the EcoRI or HindIII site by filling in the $5^{\prime}$ overhang with the Klenow fragment of DNA polymerase I in the presence of $\left[\alpha^{-32} \mathrm{P}\right] \mathrm{dATP}$ (New England Nuclear). These probes were methylated at purine residues (less than one methylation event per DNA molecule) with dimethylsulfate (Aldrich), as described (Kristie and Roizman 1988). DNA-binding reactions with methylated DNA probes were assembled, and nucleoprotein complexes were resolved as described above. Nucleoprotein complexes and free probe were isolated from the gel by electric transfer to NA45 paper (Schleicher and Schuell). Species visualized by autoradiography of the NA45 paper were eluted by incubation in $10 \mathrm{~mm}$ Tris- $\mathrm{HCl}(\mathrm{pH} 7.5), 1 \mathrm{M} \mathrm{NaCl}$, and $1 \mathrm{~mm}$ EDTA at $65^{\circ} \mathrm{C}$ for 60 min. The eluted material was extracted sequentially with phenol/chloroform $(1: 1)$ and chloroform and then was ethanol-precipitated in the presence of $30 \mu \mathrm{g}$ of carrier tRNA. Iso- 
lated DNAs were cleaved at methylated purines, as described, and resolved on $10 \%$ sequencing gels.

Copper/phenanthroline footprints were performed in situ by incubating mobility shift gels directly in the copper/phenanthroline cleavage reagents as described (Kuwabara and Sigman 1987). DNA-binding reactions with end-labeled probes were assembled and complexes resolved as described above. Cleaved nucleoprotein complexes were isolated by electric transfer to NA45 paper and purified as described above. Isolated DNAs were resolved on $10 \%$ sequencing gels. End-labeled probes were prepared as described above.

DNAse I footprinting was performed essentially as described (Galas and Schmitz 1978). DNA-binding reactions with end-labeled probes were assembled as described above. DNase I (Worthington) (200 ng) was added plus sufficient magnesium chloride to achieve a final concentration of $1 \mathrm{~mm}$. After a 20-sec incubation at room temperature, the reaction was terminated by the addition of $200 \mu \mathrm{l}$ of stop solution (10 mM EDTA, 0.14 $\mathrm{mg} / \mathrm{ml}$ tRNA, $2.67 \mathrm{M}$ ammonium acetate). Reactions were extracted sequentially with phenol/chloroform $(1: 1)$, and chloroform and were then ethanol-precipitated. Footprint patterns were revealed by electrophoresis on $10 \%$ sequencing gels.

\section{Quantitative analysis}

The densitometric analysis of mobility-shift titration autoradiograms was conducted using the methods developed to analyze footprint titration autoradiograms (Brenowitz et al. 1986; Brenowitz and Senear 1989). The model used to describe binding of the Oct-2 fusion protein to DNA containing two binding sites is depicted:

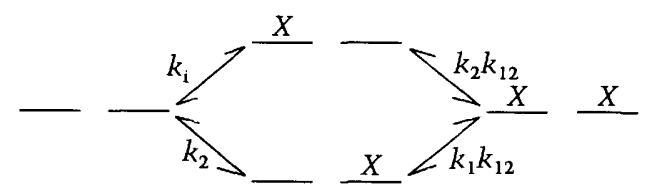

where $k_{1}$ and $k_{2}$ represent the intrinsic binding constants to sites 1 and 2 , respectively, and $k_{12}$ represents the cooperativity constant. The fraction of molecules $\left(\Theta_{i}\right)$ that are free, singly, and doubly liganded can be written, respectively:

$$
\begin{aligned}
& \Theta_{0}=\frac{1}{1+\left(k_{1}+k_{2}\right)[X]+k_{1} k_{2} k_{12}[X]^{2}} \\
& \Theta_{1}=\frac{\left(k_{1}+k_{2}\right)[X]}{1+\left(k_{1}+k_{2}\right)[X]+k_{1} k_{2} k_{12}[X]^{2}} \\
& \Theta_{2}=\frac{k_{1} k_{2} k_{12}[X]^{2}}{1+\left(k_{1}+k_{2}\right)[X]+k_{1} k_{2} k_{12}[X]^{2}}
\end{aligned}
$$

where $[X]$ is the concentration of free protein (Senear et al. 1986). The assumption that $[X]_{\text {total }}=[X]_{\text {free }}$ was made because the concentration of probe DNA in the equilibrium mixtures is small relative to the equilibrium-binding constant for the protein.

The fraction of molecules in each configuration was calculated at each protein concentration as $\theta_{i, \text { lane }}=D_{\mathrm{i}} / \mathrm{D}_{\text {total, }}$, where $D_{\mathrm{i}}$ is the density of band $i$ and $D_{\text {total }}$ is the sum of the densities of all the bands in the lane. For the probes containing two binding sites, Equations la-c, were fit to the titration data for free, singly, and doubly liganded molecules, respectively, using methods of nonlinear least-squares parameter estimation
(Johnson and Fraiser 1985). For analysis of probes containing a single protein-binding site, equations $1 \mathrm{a}-\mathrm{c}$, reduce to

$$
\begin{aligned}
& \Theta_{0}=\frac{1}{1+k_{1}[X]} \\
& \Theta_{1}=\frac{k_{1}[X]}{1+k_{1}[X]}
\end{aligned}
$$

where $\theta_{0}$ and $\theta_{1}$ represent the fraction of free and singly liganded molecules, respectively. The details of this analytical procedure will be published elsewhere.

\section{Acknowledgments}

We thank Drs. Tom Kristie, Mariano Garcia-Blanco, and Magda Konarska for critically reading the manuscript. We also thank Margarita Siafaca for preparing the manuscript and Sharon Jamison for excellent technical assistance. J.H.L. is a Leukemia Society of America, Inc., Special Fellow. R.G.C. is the recipient of a Geigy Jubiläums-Stiftung fellowship and of a Schweizerischer National Fonds stipend. This work is supported by U.S. Public Health Service grant PO1-CA42063 and, partially, Cancer Center Support (core) grant P30-CA14051 from the National Institutes of Health, from a Cooperative Agreement CDR-8803014 from the National Science Foundation (to P.A.S.), and grant GM39929 from the National Institutes of Health to M.B.

\section{References}

Ackers, G.K., A.D. Johnson, and M.A. Shea. 1982. Quantitative model for gene regulation by $\lambda$ phage repressor. Proc. Natl. Acad. Sci.2079: 1129-1133.

Ares, Jr., M., J. Chung, L. Giglio, and A.M. Weiner. 1987. Distinct factors with $\mathrm{Spl}$ and NF-A specificities bind to adjacent functional elements of the human U2 snRNA gender enhancer. Genes Dev. 1: 808-817.

Augereau, P. and P. Chambon. 1986. The mouse immunoglobulin heavy-chain enhancer: Effect on transcription in vitro and binding of proteins present in HeLa and lymphoid B cell extracts. $E M B O$ J. 5: 1791-1797.

Ballard, D.W. and A. Bothwell. 1986. Mutational analysis of the immunoglobulin heavy chain promoter region. Proc. Natl. Acad. Sci. 83: 9626-9630.

Banerii, J., L. Olson, and W. Schaffner. 1983. A lymphocyte-specific cellular enhancer is located downstream of the joining region in immunoglobulin heavy chain genes. Cell 33: 729739.

Bark, C., P. Weller, J. Zabeilski, L. Janson, and U. Petterson. 1987. A distant enhancer element is required for transcription of a U6 RNA gene. Nature 328: 356-362.

Bergman, Y., D. Rice, R. Grosschedl, and D. Baltimore. 1984. Two regulatory elements for immunoglobulin $\kappa$ light chain gene expression. Proc. Natl. Acad. Sci. 81: 7041-7045.

Bohmann, D., W. Keller, T. Dale, H.R. Scholer, G. Tebb, and I.W. Mattaj. 1987. A transcription factor which binds to the enhancers of SV40, immunoglobulin heavy chain and U2 snRNA genes. Nature 325: 268-272.

Brenowitz, M. and D.F. Senear. 1989. DNase I footprint analysis of protein-DNA binding. In Current protocols in molecular biology, (ed. F.M. Ausubel, R. Brent, R.E. Kingston, D.D. 
Moore, J.G. Seidman, J.A. Smith, and K. Struhl), pp. 12.4.112.4.16. Unit 12.4. Greene, Brooklyn, New York.

Brenowitz, M., D.F. Senear, M.A. Shea, and G.K. Ackers. 1986. Quantitative DNase footprint titration: A method for studying protein-DNA interactions. Methods Enzymol. 1130: $132-181$.

Carbon, P., S. Murgo, J.P. Ebel, A, Krol, G. Tebb, I. Mattaj. 1987. A common octamer motif binding protein is involved in the transcription of U6 snRNA by RNA polymerase III and U2 snRNA by RNA polymerase II. Cell 51: 71-79.

Church, G.M., A. Ephrussi, W. Gilbert, and S. Tonegawa. 1985. Cell-type-specific contacts to immunoglobulin enhancers in nuclei. Nature 318: 798-801.

Clerc, R.G., L.M. Corcoran, J.H. LeBowitz, D. Baltimore, and P.A. Sharp. 1988. The B-cell specific Oct-2 protein contains POU box- and homeo box-type domains. Genes Dev. 2: $1570-1581$.

Das, G., D. Henning, D. Wright, and R. Reddy. 1988. Upstream regulatory elements are necessary and sufficient for the transcription of a U6 RNA gene by RNA polymerase III. EMBO I. 7: 503-512.

Davidson, I., J.H. Xiao, R. Rosales, A. Staub, and P. Chambon. 1988. The HeLa cell protein TEF-1 binds specifically and cooperatively to two SV40 enhancer motifs of unrelated sequence. Cell 54: 931-942.

Dreyfus, M., N. Doyen, and F. Rougeon. 1987. The conserved decanucleotide from the immunoglobulin heavy chain promoter induces a very high transcriptional activity in B-cells when introduced into an heterologous promoter. EMBO $\%$ 6: $1685-1690$.

Eaton, S. and K. Calame. 1987. Multiple DNA sequence elements are necessary for the function of an immunoglobulin heavy chain promoter. Proc. Natl. Acad. Sci. 84: 76347638.

Ephrussi, A., G.M. Church. S. Tonegawa, and W. Gilbert. 1985. B lineage-specific interactions of an immunoglobulin enhancer with cellular factors in vivo. Science 227: 134-140.

Falkner, F.G. and H.Z. Zachau. 1984. Correct transcription of an immunoglobulin $\kappa$ gene requires an upstream fragment containing conserved sequence elements. Nature 310: 7174.

Fletcher, C., N. Heintz, and R.G. Roeder. 1987. Purification and characterization of OTF-1, a transcription factor regulating cell cycle expression of a human histone $\mathrm{H} 2 \mathrm{~B}$ gene. Cell 51: $773-781$.

Foster, J., J. Stafford, and C. Queen. 1985. An immunoglobulin promoter displays cell-type specificity independently of the enhancer. Nature 315: 423-425.

Fried, M. and D.M. Crothers. 1981. Equilibrium and kinetics of the lac repressor-operator interactions by polyacrylamide gel electrophoresis. Nucleic Acids Res. 9: 6505-6525.

Galas, D. and A. Schmitz. 1978. DNase footprinting: A simple method for the detection of protein-DNA binding specificity. Nucleic Acids Research 5: 3157-3170.

Garcia, J.V., L. Bich-Thuy, J. Stafford, and C. Queen. 1986. Synergism between immunoglobulin enhancers and promoters. Nature 322: 383-385.

Garcia-Blanco, M.A., R.G. Clerc, and P.A. Sharp. 1989. The DNA-binding homeo domain of the Oct-2 protein. A commentary. Genes Dev. 3: 739-745.

Garner, M.M. and A. Revzin. 1981. A gel electrophoresis method for quantifying binding of proteins to specific DNA regions: Applications to components of the Escherichia coli lactose operon regulatory system Nucleic Acids Res. 9: 3047-3060.
Gerster, T. and R.G. Roeder. 1988. A herpesvirus trans-activating protein interacts with transcription factor OTF-1 and other cellular proteins. Proc. Natl. Acad. Sci. 855: 63476351.

Gerster, T., P. Matthias, M. Thali, J. Jiricny, and W. Schaffner. 1987. Cell type-specificity elements of the immunoglobulin heavy chain gene enhancer. EMBO I. 6: 1323-1330.

Gillies, S.D., S.L. Morrison, V.T. Oi, and S. Tonegawa. 1983. A tissue-specific transcriptional enhancer element is located in the major intron of a rearranged immunoglobulin heavy chain gene. Cell 33: 717-728.

Gopal, T.V., J. Shimada, A.W. Baur, and A.W. Nienhuis. 1985. Contribution of promoter to tissue-specific expression of the mouse immunoglobulin $\mathrm{k}$ gene. Science 229: 1102-1104.

Grosschedl, R. and D. Baltimore. 1985. Cell type specificity of immunoglobulin gene expression is regulated by at least three DNA sequence elements. Cell 41: 885-897.

Herr, W., R.A. Sturm, R.G. Clerc., L.M. Corcoran, D. Baltimore, P.A. Sharp, H.A. Ingraham, M.G. Rosenfeld, M. Finney, G. Ruvkin, and H.R. Horvitz. 1988. The POU domain: A large conserved region in the mammalian pit-1, oct -1 , oct- 2 and C. elegans unc-86 gene products. Genes Dev. 2: 1513-1516.

Johnson, A.D., B.J. Meyer, and M. Ptashne. 1979. Interactions between bound repressors govern regulation by the lambda phage repressor. Proc. Natl. Acad. Sci. 76: 5061-5065.

Johnson, M.L. and S.G. Frasier. 1985. Nonlinear least squares analysis. Methods Enzymol. 117: 301-342.

Jones, N.C., P.W.J. Rigby, and B. Ziff. 1988. Trans-acting protein factors and the regulation of eukaryotic transcription: Studies on DNA tumor viruses. Genes Dev. 2: 267-281.

Kemler, R., E. Schreiber, M.M. Müller, P. Matthias, and W. Schaffner. 1989. Octamer transcription factors bind to two different sequence motifs of the immunoglobulin heavy chain promoter. $E M B O$ I. 8: 2001-2008.

Ko, H.-S., P. Fast, W. McBride, and L.M. Staudt. 1988. A human protein specific for immunoglobulin octamer DNA motif contains a functional homeobox domain. Cell 55: 135-144.

Kristie, T.M. and B. Roizman. 1988. Differentiation and DNA contact points of host proteins binding at the cis site for virion-mediated induction of $\alpha$ genes and herpes simplex virus. J. Virol. 62: 1145-1157.

Krol, A., P. Carbon, J.P. Ebel, and B. Appel. 1987. Xenopus tropicalis U6 snRNA genes transcribed by RNA polymerase III contain the promoter elements used by pol II dependent $U$ snRNA genes. Nucleic Acids Res. 15: 2463-2478.

Kuwabara, M.D. and D.S. Sigman. 1987. Footprinting DNAprotein complexes in situ following gel retardation assays using 1,10-phenanthroline-copper ion: Escherichia coli RNA polymerase-lac promoter complexes. Biochemistry 26: $7234-7238$.

Landolfi, N.F., J.D. Capra, and P.W. Tucker. 1986. Interaction of cell type-specific nuclear proteins with immunoglobulin $V_{\mathbf{H}}$ promoter region sequences. Nature 323: 548-551.

Landolfi, N.F., X. Yin, J.D. Capra, and P.W. Tucker. 1988. A conserved heptamer upstream of the $\mathrm{IgH}$ promoter region OCTAmer can be the site of a coordinate protein-DNA interaction. Nucleic Acids Res. 16: 5503-5514.

LeBowitz, J.H., T. Kobayashi, L. Staudt, D. Baltimore, and P.A. Sharp. 1988. Octamer-binding proteins from B or HeLa cells stimulate transcription of the immunoglobulin heavy chain promoter in vitro. Genes Dev. 2: 1227-1237.

Lenardo, M., J.W. Pierce, and D. Baltimore. 1987. Protein binding sites in Ig gene enhancers determine transcriptional activity and inducibility. Science 236: 1573-1577.

Mangin, M., M. Ares Jr., and A.M. Weiner. 1986. Human U2 
small nuclear RNA genes contain an upstream enhancer. EMBO I. 5: 987-995.

Maniatis, T., S. Goodbourn, J.A. Fischer. 1987. Regulation of inducible and tissue specific gene expression. Science 236: $1237-1245$.

Mason, J.O., G.T. Williams, and M.S. Neuberger. 1985. Transcription cell type specificity is conferred by an immunoglobulin VH gene promoter that includes a functional consensus sequence. Cell 41: 497-487.

Mattaj, I.W., S. Lienhard, J. Jiricny, and E.M. de Robertis. 1985. An enhancer-like sequence within the Xenopus U2 gene promoter facilitates the formation of stable transcription complexes. Nature 316: 163-167.

Mizushima-Sugano, J. and R.G. Roeder. 1986. Cell-type-specific transcription of an immunoglobulin $\kappa$ light chain in vitro. Proc. Natl. Acad. Sci. 83: 8511-8515.

Müller, M.M., S. Ruppert, W. Schaffner, and P. Matthias. 1988. A cloned octamer transcription factor stimulates transcription from lymphoid-specific promoters in non-B cells. $\mathrm{Na}$ ture 336: 544-551.

Murphy, J.T., J.M. Skuzeski, E. Lund. T.H. Steinberg, R.R. Burgess, and J.E. Dahlberg. 1987. Functional elements of the Ul snRNA promoter. Identification of 5 separate regions required for efficient transcription and template competition. J. Biol. Chem. 262: 1795-1803.

O'Neill, E.A. and T.J. Kelly. 1988. Purification and characterization of nuclear factor III (origin initiation factor C). Sequence-specific DNA binding protein required for efficient initiation of adenovirus DNA replication. /. Biol. Chem. 263: 934-937.

Parslow, T.G., D.L. Blair, W.J. Murphy, D.K. Granner, and K.R. Yamamoto. 1984. Structure of the $5^{\prime}$ ends of immunoglobulin genes: A novel conserved sequence. Proc. Natl. Acad. Sci. 81: 2650-2654.

Peterson, C.L. and K.L. Calame. 1987. Complex protein binding within the mouse immunoglobulin heavy-chain enhancer. Mol. Cell Biol. 7: 4194-4203.

Picard, D. and W. Schaffner. 1985. Cell-type preference of the immunoglobulin $\kappa$ and $\lambda$ gene promoters. EMBO $/$. 4: 28312838.

Poellinger L. and R.G. Roeder. 1989. Octamer transcription factors 1 and 2 each bind to two different functional elements in the immunoglobulin heavy-chain promoter. Mol. Cell Biol. 9: 747-756.

Poellinger, L., B.K. Yoza, and R.G. Roeder. 1989. Functional cooperativity between protein molecules bound at two distinct sequence elements of the immunoglobulin heavychain promoter. Nature 337: 573-576.

Pruijn, G.J.M., W. van Driel, and P.C. van der Vliet. 1986. Nuclear factor III, a novel sequence specific DNA binding protein from HeLa cells stimulating adenovirus DNA replication. Nature 322: 656-659.

Roebuck, K.A., R.J. Walker, and W.E. Stumph. 1987. Multiple functional motifs in the chicken U1 RNA gene enhancer. Mol. Cell Biol. 7: 4185-4193.

Scheidereit, C., A. Heguy, and R.G. Roeder. 1987. Identification and purification of a human lymphoid specific octamerbinding protein (OTF-2) that activates transcription of an immunoglobulin promoter in vitro. Cell 51: 783-793.

Scheidereit, C., J.A. Cromlish, T. Gerster, K. Kawakami, C.G. Balmaceda, R.A. Currie, and R.G. Roeder. 1988. A human lymphoid-specific transcription factor that activates immunoglobulin genes is a homeobox protein. Nature 336: $551-$ 557.

Schlokat, U., D. Bohmann, H. Scholer, and P. Gruss. 1986. Nuclear factors binding specific sequences within the immuno- globulin enhancer interact differentially with other enhancer elements. EMBO I. 5: 3251-3258.

Sen, R. and D. Baltimore. 1986. Multiple factors interact with the immunoglobulin enhancer sequences. Cell 46: 705716.

Senear, D.F., M. Brenowitz, M.A. Shea, and G.K. Ackers. 1986. Energetics of cooperative protein-DNA interactions: Comparison between quantitative deoxyribonuclease footprint titration and filter binding. Biochemistry 25: 7344-7354.

Singh, H., R. Sen, D. Baltimore, and P.A. Sharp. 19896. A nuclear factor that binds to a conserved sequence motif in transcriptional control elements of immunoglobulin genes. Nature 319: 154-158.

Sive, H.L and R.G. Roeder. 1986. The interaction of a common factor with conserved promoter and enhancer sequences in histone $\mathrm{H} 2 \mathrm{~B}$, immunoglobulin and $\mathrm{U} 2$ small nuclear (sn) RNA genes. Proc. Natl. Acad. Sci. 83: 6382-6386.

Sive, H.L., N. Heintz, and R.G. Roeder. 1986. Multiple sequence elements are required for maximal in vitro transcription of a human histone H2B gene. Mol. Cell Biol. 6: 3329-3340.

Staudt, L.M., R.G. Clerc, H. Singh, J. LeBowitz, P.A. Sharp, and D. Baltimore. 1988. Molecular cloning of a lymphoid-specific cDNA encoding a protein that binds to the regulatory octamer motif. Science 241: 577-580.

Staudt, L.M., H. Singh, R. Sen, T. Wirth, P.A. Sharp, and D. Baltimore. 1986. A lymphoid-specific protein binding to the octamer motif of immunoglobulin genes. Nature 323: 640643.

Sturm, R.A. and W. Herr. 1988. The POU domain is a bipartite DNA binding structure. Nature 366: 601-604.

Sturm, R.A., G. Das, and W. Herr. 1988. The ubiquitous octamer-binding protein Oct-1 contains a POU domain with a homeo box subdomain. Genes Dev. 2: 1582-1599.

Sturm, R., T. Baumruker, R. Franza, Jr., and W. Herr. 1987. A $100-\mathrm{kD}$ HeLa cell octamer binding protein (OBP100) interacts differently with two separate octamer-related sequences within the SV40 enhancer. Genes Dev. 1: 11471160.

Topol, J., D.M. Ruben, and C.S. Parker. 1985. Sequences required for the in vitro transcriptional activation of a Drosophila hsp70 gene. Cell 42: 527-537.

Tsai, S.Y., M.-J, Tsai, and B.W. O'Malley. 1989. Cooperative binding of steroid hormone receptors contributes to transcriptional synergism at target enhancer elements. Cell 57: $443-448$.

Wang, J., K. Nishiyama, K. Araki, D. Kitamura, and T. Watanabe. 1987. Purification of an octamer sequence (ATGCAAAT|-binding protein from human B-cells. Nucleic Acids Res. 15: 10105-10116.

Wasylyk, C. and B. Wasylyk. 1986. The immunoglobulin heavy-chain B-lymphocyte enhancer stimulates transcription in non-lymphoid cells. EMBO /. 5: 553-560.

Weinberger, J., D. Baltimore, and P.A. Sharp. 1986. Distinct factors bind to apparently homologous sequences in the immunoglobulin heavy-chain enhancer. Nature 322: 846-848.

Weinberger, J., P.S. Jat, and P.A. Sharp. 1988. Localization of a repressive sequence contributing to B-cell specificity in the immunoglobulin heavy-chain enhancer. Mol. Cell Biol. 8: 988-992.

Wirth, T., L. Staudt, and D. Baltimore. 1987. An octamer oligonucleotide upstream of a TATA motif is sufficient for lymphoid-specific promoter activity. Nature 329: 174-177. 


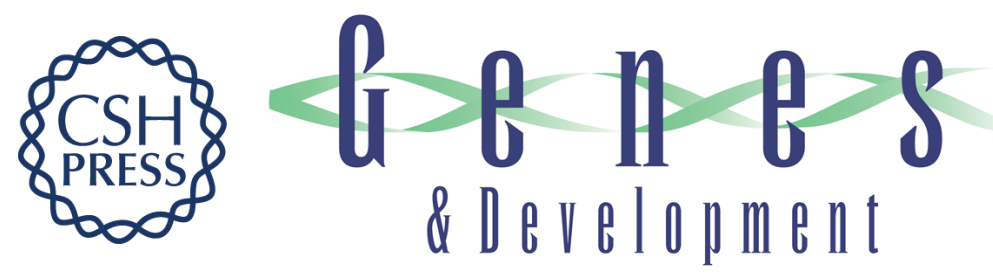

\section{The Oct-2 protein binds cooperatively to adjacent octamer sites.}

J H LeBowitz, R G Clerc, M Brenowitz, et al.

Genes Dev. 1989, 3:

Access the most recent version at doi:10.1101/gad.3.10.1625

$\begin{array}{ll}\text { References } & \begin{array}{l}\text { This article cites } 78 \text { articles, } 27 \text { of which can be accessed free at: } \\ \text { http://genesdev.cshlp.org/content/3/10/1625.full.html\#ref-list-1 }\end{array}\end{array}$

License

Email Alerting Receive free email alerts when new articles cite this article - sign up in the box at the top Service right corner of the article or click here.

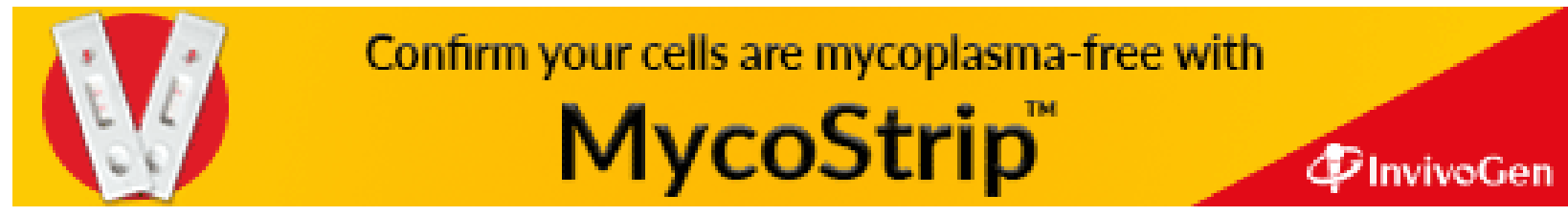

